\title{
Triterpenoids Isolated from Alnus japonica Inhibited LPS-Induced Inflammatory Mediators in HT-29 Cells and RAW264.7 Cells
}

\author{
Mina Lee, ${ }^{a, b}$ Sun-Yup Shim, ${ }^{a, c}$ and Sang Hyun Sung ${ }^{*, d}$ \\ ${ }^{a}$ College of Pharmacy, Sunchon National University; 255 Jungangno, Suncheon-si, Jeonnam 57922, Republic of \\ Korea: ${ }^{b}$ Suncheon Research Center for Natural Medicines; 255 Jungangno, Suncheon-si, Jeonnam 57922, Republic \\ of Korea: ${ }^{c}$ Research Institute of Life and Pharmaceutical Sciences; 255 Jungangno, Suncheon-si, Jeonnam 57922, \\ Republic of Korea: and ${ }^{d}$ College of Pharmacy and Research Institute of Pharmaceutical Sciences, Seoul National \\ University; 599 Gwanak-ro, Gwanak-gu, Seoul 08826, Republic of Korea.
}

Received November 18, 2016; accepted May 17, 2017

\begin{abstract}
Alnus japonica (Betulaceae) is a broad-leaved tree easily found in damp regions within the mountains of Korea and Japan. Four triterpenoids (1-4) from the fruits of $A$. japonica, including the newly isolated $3 \beta$ hydroxy-lanost-9(11),23(24)-dien-25,26-diol (3), inhibited the lipopolysaccharide (LPS)-induced expression of the chemotactic cytokine interleukin (IL)-8 and nitric oxide (NO) production in HT-29 colon epithelial cells and RAW264.7 macrophages, respectively. Among these triterpenoids, compound 4, which showed the most potent inhibitory activity, effectively down-regulated LPS-induced protein expression of inducible nitric oxide synthase (iNOS) in RAW264.7 cells and in HT-29 cells. Also, compound 4 concentration-dependently inhibited the levels of LPS-induced pro-inflammatory cytokines, IL-1 $\beta$ and IL-6 in macrophage cells. These triterpenoids isolated from $A$. japonica fruits are thought to contribute to the anti-inflammatory activities of macrophage and colon epithelial cells, which are important for regulating the colon immune system. They are expected to be potential candidates for therapeutic agents against inflammatory bowel disease.
\end{abstract}

Key words Alnus japonica; triterpenoid; RAW264.7 cell; HT-29 cell; inflammatory bowel disease (IBD)

Inflammation is an important defense response against body tissue injuries and invading pathogens. Acute inflammation is a necessary reaction of the innate immune system to protect the host from a variety of etiologic agents such as chemical injuries, thermal and mechanical stress, pathogens, antigens, and infections. ${ }^{1,2)}$ In contradistinction to acute inflammation, continuous stimulation by etiologic agents extending up to months or years cause excess levels of inflammatory mediators in macrophages. ${ }^{3)}$ This is called the chronic inflammatory response, which may induce a variety of diseases including inflammatory bowel disease (IBD). ${ }^{4)}$ Inflammatory bowel diseases including ulcerative colitis (UC) and Crohn's disease (CD) are chronic relapsing disorders of the gastrointestinal tract characterized pathologically by epithelial injury and intestinal inflammation. ${ }^{5)}$ The definite etiology of IBD remains unclear, but recent reports indicate that the innate immune system is crucial in the pathology of intestinal inflammation. $^{4,6)}$

Cytokines play a pivotal role in the regulation of the intestinal immune system. The levels of various pro-inflammatory cytokines are elevated in patients with IBD. ${ }^{7)}$ These cytokines are quickly stimulated and secreted by inflammatory cells, and have an effect on the induction, amplification, prolongation, and termination of inflammation. ${ }^{7}$ Nitric oxide (NO) and inducible nitric oxide synthase (iNOS) are main factors in the inflammatory process. NO helps macrophages with immunological activity rebuff etiologic agents. ${ }^{4)}$ iNOS is an enzyme that produces NO when induced by lipopolysaccharide (LPS) or various pro-inflammatory cytokines and a high level of human iNOS is measured in macrophages from patients who have infections or inflammatory diseases. ${ }^{8)}$ Therefore, down-regulation of the production of NO and iNOS may thus suppress or prevent a variety of inflammatory diseases. The production of pro-inflammatory cytokines such as interleukin (IL) $-1 \beta$ and IL- 6 leads to acute and chronic inflammatory diseases and is stimulated by the activation of nuclear factor $\kappa \mathrm{B}$ $(\mathrm{NF}-\kappa \mathrm{B})$, which is involved in the regulation of many inflammation-associated genes. IL- 8 is secreted from the intestinal epithelium against pathogenic infections and various stimuli in the early stages of inflammation, and an increase in IL-8 has been observed in the intestinal tissue of IBD patients. ${ }^{9)}$ As the intestinal inflammatory mediator in IBD, macrophages as well as intestinal epithelial cells play a significant role in the intestinal immune response. Among the primary mediators of chronic inflammation such as reactive oxygen species, hydrolytic enzymes, cytokines and other growth factors, we focused on evaluating the expression of inflammatory cytokines such as IL-1 $\beta$, IL-6, IL-8, and iNOS related to NO production. ${ }^{10)}$

The Alnus japonica STEud. (Betulaceae) is a broad-leaved tree easily found in damp regions in the mountain valleys of Korea and Japan. A. japonica have been used as a traditional medicine to treat alcoholism, diarrhea, hemorrhage, antipyretic fever and burn injuries. ${ }^{11,12)}$ There have been many studies on A. japonica demonstrating anti-tumor, anti-inflammatory, antioxidative, and anti-obesity effects. ${ }^{13)}$ However, anti-inflammatory activity associated with IBD have not been investigated yet. As part of our ongoing screening program to evaluate the anti-inflammatory potential of natural compounds, we investigated the in vitro anti-inflammatory activities of $A$. japonica. This led to the isolation of four triterpenoids, which were evaluated for the down-regulation of LPS-stimulated inflammatory response in macrophages, RAW264.7 cells and colon epithelial HT-29 cells. 


\section{MATERIALS AND METHODS}

Plant Material The A. japonica fruits were collected in the Nambu forest of Seoul, Beagwoon Mountain, Gwangyang city, Jeollanam-do, Korea. These Alnus species were identified by Dr. Jong Hee Park, a professor at Pusan National University. A voucher specimen (SCNUP003-F1) was deposited at the laboratory of Pharmacognosy, College of Pharmacy, Sunchon National University, Korea.

Extraction and Isolation The fruits of $A$. japonica $(1.5 \mathrm{~kg})$ were dried, smashed and extracted three times with $80 \%$ methanol $(4 \mathrm{~L})$ for $3 \mathrm{~h}$ using ultrasonication. The residue was concentrated in vacuo to yield crude extract $(419.1 \mathrm{~g})$. The extract was suspended in $\mathrm{H}_{2} \mathrm{O}$ and fractioned in a regular sequence with $n$-hexane (4L), $\mathrm{CHCl}_{3}(4 \mathrm{~L}), n$ - $\mathrm{BuOH}(4 \mathrm{~L})$ and $\mathrm{H}_{2} \mathrm{O}$ to obtain residues of $29.5,47.6,251.6$, and $62.7 \mathrm{~g}$, respectively. Among these fractions, the $\mathrm{CHCl}_{3}$ fractions showed a significant inhibition effect on LPS-induced NO production in RAW264.7 cell. These fractions were used for further isolation work. The $\mathrm{CHCl}_{3}$ fraction was used for silica gel column chromatography using a gradient of $\mathrm{CHCl}_{3}-\mathrm{MeOH}-\mathrm{H}_{2} \mathrm{O}$ to obtain fifteen fractions $(\mathrm{C} 1-\mathrm{C} 15)$. $\mathrm{C} 4$ was subjected to medium pressure liquid chromatography (MPLC) (RediSep silica gel; $\left.\mathrm{CHCl}_{3}-\mathrm{MeOH}, 15: 1 \rightarrow \mathrm{MeOH}, 30 \mathrm{~mL} / \mathrm{min}\right)$ to obtain six fractions (C4-1-C4-6). Compound 1 (4.1 mg) was obtained from $\mathrm{C} 4-3$ by column chromatography on the Sephadex LH-20 $\left(\mathrm{CHCl}_{3}-\mathrm{MeOH}, 1: 1\right)$. C4-5 was used for MPLC (RediSep silica gel; $\mathrm{CHCl}_{3} \rightarrow \mathrm{MeOH} ; 22 \mathrm{~mL} / \mathrm{min}$ ) to obtain seven fractions (C4-5-1-C4-5-7). C4-5-6 was used for preparative HPLC (polymeric gel filtration, $500 \times 20 \mathrm{~mm}, n$-hexane-EtOAc $3: 1 \rightarrow 1: 1,4 \mathrm{~mL} / \mathrm{min})$ to obtain thirty fractions (C4-5-6-1C4-5-6-30). Compounds 2-4 were obtained by recrystallization from C4-5-6-7, C4-5-6-9, and C4-5-6-10, respectively.

$3 \beta$-Hydroxy-lanost-9(11),23(24)-dien-25,26-diol (3), whitish amorphous powder; $\mathrm{mp}\left({ }^{\circ} \mathrm{C}\right): 203.5-205.5 ;[\alpha]_{\mathrm{D}}^{25}+40.3(c=1.0$ $\left.\mathrm{CHCl}_{3}-\mathrm{MeOH}=1: 1\right)$; IR $(\mathrm{KBr}) v_{\max }\left(\mathrm{cm}^{-1}\right): 3402,2938,1714$, 1456, 1375, 1045; ${ }^{1} \mathrm{H}-\mathrm{NMR}\left(500 \mathrm{MHz}, \mathrm{C}_{5} \mathrm{D}_{6} \mathrm{~N}\right)$ and ${ }^{13} \mathrm{C}-\mathrm{NMR}$ $\left(125 \mathrm{MHz}, \mathrm{C}_{5} \mathrm{D}_{6} \mathrm{~N}\right)$ : Table 1; High resolution (HR)-FAB-MS (negative mode): $m / z 457.0828[\mathrm{M}-\mathrm{H}]^{-}$(Calcd for $\mathrm{C}_{30} \mathrm{H}_{49} \mathrm{O}_{3}$, 457.0826).

Cell Culture, Cell Viability and NO Production Human colonic epithelial cells (HT-29) and mouse macrophage cells (RAW264.7) were acquired from the Korean Cell lines bank (Seoul, Korea). These cells were cultured as monolayers in a $37^{\circ} \mathrm{C}$ humidified atmosphere with $5 \% \mathrm{CO}_{2}$. The cells were cultured in Dulbecco's modified Eagle's medium (DMEM) (Hyclone, U.S.A.) with $10 \%$ heat-inactivated fetal bovine serum (FBS) (Hyclone, U.S.A.) containing $100 \mu \mathrm{g} / \mathrm{mL}$ streptomycin and $100 \mathrm{IU} / \mathrm{mL}$ penicillin. In the present study, four triterpenoids at final concentrations of 5-25 $\mu \mathrm{M}$ were added to HT-29 cells and RAW264.7 cells for $1 \mathrm{~h}$ and the cells were treated with LPS $(1 \mu \mathrm{g} / \mathrm{mL})$ for $24 \mathrm{~h}$. Cell viability and NO production were determined with 3-(4,5-dimethylthiazol2-yl)-2,5-diphenyltetrazolium bromide (MTT) assay (Dojindo, Japan) and Griess reagent, respectively. ${ }^{14}$

Expression of Pro-inflammatory Cytokines ${ }^{14)}$ The level of IL-8 was determined using enzyme-linked immunosorbent assay (ELISA) kits (BD OptEIA ${ }^{\mathrm{TM}}$, CA, U.S.A.) in HT-29 human colonic epithelial cells. The levels of IL- $1 \beta$ and IL-6 were detected by mouse ELISA kits (Cusabio, Wuhan, China) in RAW264.7 mouse macrophage cells.
Table 1. ${ }^{1} \mathrm{H}$ - and ${ }^{13} \mathrm{C}-\mathrm{NMR}$ Data of Compound 3

\begin{tabular}{|c|c|c|}
\hline Position & $\delta_{\mathrm{H}}(J$ in $\mathrm{Hz})$ & $\delta_{\mathrm{C}}$ \\
\hline 1 & $1.81,1.52, \mathrm{~m}$ & $36.8, \mathrm{t}$ \\
\hline 2 & $1.94, \mathrm{~m}$ & $28.7, \mathrm{t}$ \\
\hline 3 & $3.43, \mathrm{~m}$ & $78.0, \mathrm{~d}$ \\
\hline 4 & & $39.7, \mathrm{~s}$ \\
\hline 5 & $0.99, \mathrm{~m}$ & $53.0, \mathrm{~d}$ \\
\hline 6 & $1.72,1.54, \mathrm{~m}$ & $21.8, \mathrm{t}$ \\
\hline 7 & $1.63,1.21, \mathrm{~m}$ & $28.5, \mathrm{t}$ \\
\hline 8 & $2.20, \mathrm{~m}$ & $42.1, \mathrm{~d}$ \\
\hline 9 & & $149.2, \mathrm{~s}$ \\
\hline 10 & & $39.8, \mathrm{~s}$ \\
\hline 11 & $5.27, \mathrm{~d}(5.5)$ & $115.0, \mathrm{~d}$ \\
\hline 12 & $2.05,1.89 \mathrm{~m}$ & $37.4, \mathrm{t}$ \\
\hline 13 & & $44.6, \mathrm{~s}$ \\
\hline 14 & & $47.3, \mathrm{~s}$ \\
\hline 15 & $1.40, \mathrm{~m}$ & $34.1, \mathrm{t}$ \\
\hline 16 & $1.27, \mathrm{~m}$ & $28.3, \mathrm{t}$ \\
\hline 17 & $1.65, \mathrm{~m}$ & $51.5, \mathrm{~d}$ \\
\hline 18 & $0.69, \mathrm{~s}$ & $14.7, \mathrm{q}$ \\
\hline 19 & $1.12, \mathrm{~s}$ & $22.6, \mathrm{q}$ \\
\hline 20 & $1.54, \mathrm{~m}$ & $36.8, \mathrm{~d}$ \\
\hline 21 & $0.96, \mathrm{~d}(6.3)$ & $18.7, \mathrm{q}$ \\
\hline 22 & $2.30,1.89, \mathrm{~m}$ & $39.7, \mathrm{t}$ \\
\hline 23 & $6.12, \operatorname{td}(15.5,8.1)$ & $127.0, \mathrm{~d}$ \\
\hline 24 & $6.00, \mathrm{~d}(15.5)$ & $138.2, \mathrm{~d}$ \\
\hline 25 & & $73.2, \mathrm{~s}$ \\
\hline \multirow[t]{2}{*}{26} & $3.95, \mathrm{~d}(10.5)$ & $71.2, \mathrm{t}$ \\
\hline & $3.90, \mathrm{~d}(10.5)$ & \\
\hline 27 & $1.65, \mathrm{~s}$ & $25.5, \mathrm{~s}$ \\
\hline 28 & $1.29, \mathrm{~s}$ & $28.9, \mathrm{q}$ \\
\hline 29 & $1.07, \mathrm{~s}$ & $16.5, \mathrm{q}$ \\
\hline 30 & $0.77, \mathrm{~s}$ & $18.6, \mathrm{q}$ \\
\hline
\end{tabular}

${ }^{1} \mathrm{H}-$ and ${ }^{13} \mathrm{C}-\mathrm{NMR}$ data were measured at 500 and $125 \mathrm{MHz}$ in $\mathrm{C}_{5} \mathrm{D}_{6} \mathrm{~N}$, respectively. Multiplicity was determined by DEPT experiments.

Western Blotting Cells were lysed with lysis buffer (50 mm Tris, $\mathrm{pH}$ 7.4, $1 \mathrm{~mm}$ ethylenediaminetetraacetic acid (EDTA), $0.1 \%$ Triton X-100, $1 \mathrm{~mm}$ phenylmethylsulfonyl fluoride (PMSF), $25 \mu \mathrm{g} / \mathrm{mL}$ leupeptin, and $20 \mu \mathrm{g} / \mathrm{mL}$ pepstatin) on ice for $20 \mathrm{~min}$. After centrifugation at $12000 \times \boldsymbol{g}$ for $20 \mathrm{~min}$, the protein concentration in the supernatant was determined. Protein samples were subjected to $10 \%$ sodium dodecyl sulfate-polyacrylamide gel electrophoresis and transferred to polyvinylidene difluoride membranes (Millipore, Bedford, MA, U.S.A.). The membranes were blocked with TBST [10mm Tris ( $\mathrm{pH} 7.4$ ), $100 \mathrm{~mm} \mathrm{NaCl}$, and $0.5 \%$ Tween 20] containing $5 \%$ bovine serum albumin (BSA) for $30 \mathrm{~min}$ at RT and incubated with anti-iNOS antibody (1:1000, Cell Signaling, MA, U.S.A.) in TBST containing $1 \%$ milk powder overnight at $4^{\circ} \mathrm{C}$. Then, the membranes were incubated with horseradish peroxidase (HRP) with conjugated anti-mouse-immunoglobulin G (IgG) (1:1000, Santa Cruz, CA, U.S.A.). The membranes were visualized by enhanced chemiluminescence (ECL-kit, Thermo, U.S.A.) and detected using a Bio imagingsystem (MicroChemi 4.2 Chemilumineszenz-System, Israel).

Statistical Analysis The evaluation of statistical significance was determined by a "one-way ANOVA" test using a computerized statistical package. All data were expressed as means \pm standard deviation (S.D.) of at least three independent 
experiments, and statistical significance was shown at $p<0.05$.

\section{RESULTS AND DISCUSSION}

The increase of inflammatory mediators in the inflamed mucosa indicates that the activation of the intestinal immune system plays a central role in the pathophysiology of chronic mucosal inflammation and the associated clinical symptoms. ${ }^{5}$ Mucosal and systemic concentrations of pro-inflammatory cytokines are elevated in IBD. ${ }^{7)}$ To discover more anti-inflammatory candidates, we investigated natural products, which are used as traditional medicines and have attracted attention, due to the growing interest in their health benefits. In the course of searching for anti-inflammatory natural product, we further investigated the $A$. japonica fruit, which was previously reported to have the anti-adipogenic activities based on studying the diarylheptanoids isolated from the extract fractions. ${ }^{15}$ ) In the present study, we attempted to isolate other phytochemicals, with the goal of preventing IBD, and screened the anti-inflammatory effects of the constituents isolated from $A$. japonica employing RAW264.7 and HT-29 cells as an in vitro assay system. The four triterpenoids (1-4) were obtained from the $\mathrm{CHCl}_{3}$ fraction of $80 \%$ methanolic extract of $A$. japonica fruits were on successive normal phase column chromatography using a multi-gradient as the mobile phase (Fig. 1).

Compound 3 was isolated as a whitish amorphous powder, $[\alpha]_{\mathrm{D}}^{25}+40.3\left(c=1.0 \mathrm{CHCl}_{3}-\mathrm{MeOH}=1: 1\right)$. The molecular formu- la was determined to be $\mathrm{C}_{30} \mathrm{H}_{50} \mathrm{O}_{3}$ from the negative HR-FABMS at $m / z 457.0828[\mathrm{M}-\mathrm{H}]^{-}$(Calcd for $\mathrm{C}_{30} \mathrm{H}_{49} \mathrm{O}_{3}, 457.0826$ ). The ${ }^{1} \mathrm{H}-\mathrm{NMR}$ spectrum of compound 3 showed evidence of the presence of seven tert $-\mathrm{CH}_{3}$ groups $\left[\delta_{\mathrm{H}} 1.65(3 \mathrm{H}, \mathrm{s}, \mathrm{H}-27)\right.$, 1.29 (3H, s, H-28), 1.12 (3H, s, H-19), 1.07 (3H, s, H-29), 0.77 (3H, s, H-30), 0.69 (3H, s, H-18)], two olefinic double bonds $\left[\delta_{\mathrm{H}} 5.27(1 \mathrm{H}\right.$, brd, $J=5.5 \mathrm{~Hz}, \mathrm{H}-11), 6.12(1 \mathrm{H}, \mathrm{td}, J=15.5$, $8.1 \mathrm{~Hz}, \mathrm{H}-23), 6.00(1 \mathrm{H}, \mathrm{d}, J=15.5 \mathrm{~Hz}, \mathrm{H}-24)]$, geminal protons $\left[\delta_{\mathrm{H}} 3.95(1 \mathrm{H}, \mathrm{d}, J=10.5 \mathrm{~Hz}, \mathrm{H}-26)\right.$ and $3.90(1 \mathrm{H}, \mathrm{d}, J=10.5 \mathrm{~Hz}$, $\mathrm{H}-26)]$. The $J$-value $(15.5 \mathrm{~Hz})$ between $\mathrm{H}-23$ and $\mathrm{H}-24$ indicated that the olefinic bond was trans-type. The ${ }^{13} \mathrm{C}$-NMR spectrum exhibited 30 carbon signals sorted by distortionless enhancement by polarization transfer (DEPT) experiment as seven tert $-\mathrm{CH}_{3}$ groups $\left[\delta_{\mathrm{C}} 28.9(\mathrm{C}-28), 22.6(\mathrm{C}-19), 18.7(\mathrm{C}-21)\right.$, 18.6 (C-30), 16.5 (C-29), 14.7 (C-18)], eight methylenes including one oxygenated carbon $\left[\delta_{\mathrm{C}} 71.2(\mathrm{C}-26), 39.7(\mathrm{C}-22), 37.4\right.$ (C-12), 36.8 (C-1), 34.1 (C-15), 28.7 (C-2), 28.5 (C-7), 28.3 (C-16), 21.8 (C-6)], eight hybridized methines including one oxygenated carbon and three olefinic carbons $\left[\delta_{\mathrm{C}} 138.2(\mathrm{C}-24)\right.$, 127.0 (C-23), 115.0 (C-11), 78.0 (C-3), 53.0 (C-5), 51.5 (C-17), $42.1(\mathrm{C}-8), 36.8(\mathrm{C}-20)]$, five quaternary $s p^{3}$-carbons $\left[\delta_{\mathrm{C}} 73.2\right.$ (C-25), 47.3 (C-14), 44.6 (C-13), 39.7 (C-4), 25.5 (C-27)], and one quaternary $s p^{2}$-carbon $\left[\delta_{\mathrm{C}} 149.2(\mathrm{C}-9)\right]$, suggesting a tetracyclic triterpenoid. The location of hydroxyl groups was evidenced by the relative downfield signals of H-3, H-26 and heteronuclear multiple bond correlation (HMBC) correlations: H-3 to C-28/C-29; H-26 to C-25; H-23/H-24 to C-25 (Fig. 2).<smiles>C/C(=C\CC[C@@H](C)[C@H]1CC[C@]2(C)[C@H]3CC[C@H]4C(C)(C)[C@@H](O)CC[C@]4(C)C3=CC[C@]12C)C(=O)O</smiles><smiles>C[C@H](C/C=C/C(C)(O)CO)[C@H]1CC[C@]2(C)C3CCC4C(C)(C)[C@@H](O)CC[C@]4(C)C3=CC[C@]12C</smiles>

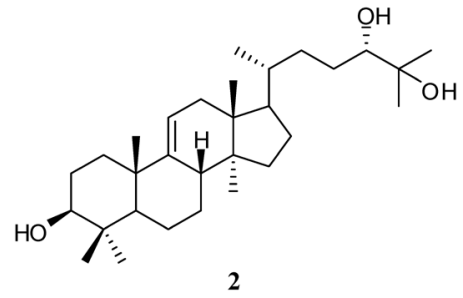<smiles>C=C(C)[C@H](O)CC[C@@](C)(O)C1CC[C@]2(C)C1CCC1C2CCC2C(C)(C)[C@@H](O)CC[C@]12C</smiles>

Fig. 1. Structures of Triterpenoids Isolated from A. japonica
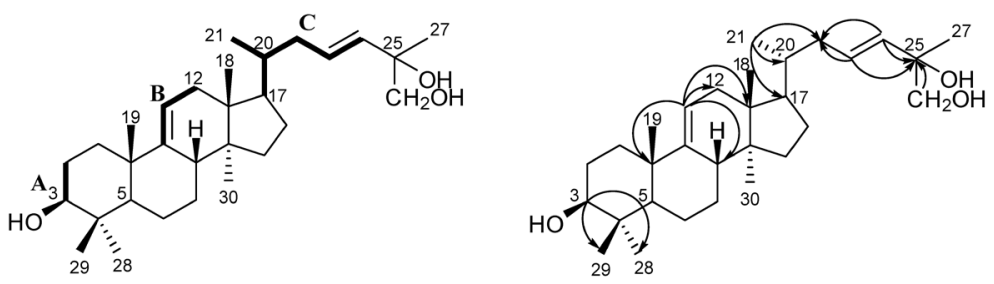

: : $^{\mathrm{H}-{ }^{-} \mathrm{H} \text { COSY correlation }}$

Fig. 2. ${ }^{1} \mathrm{H}-{ }^{1} \mathrm{H}$ COSY, HMBC and NOESY Correlations of Compound $\mathbf{3}$ 
The ${ }^{1} \mathrm{H}-{ }^{1} \mathrm{H}$ correlation spectroscopy (COSY) and heteronuclear single quantum correlation (HSQC) experiments revealed the following key fragments: $\mathrm{CH}_{2}-\mathrm{CH}(\mathrm{OH})-(\mathrm{A}) ; \mathrm{C}(\mathrm{C})=\mathrm{CH}-$ $\mathrm{CH}_{2}-(\mathrm{B}) ; \mathrm{CH}\left(\mathrm{CH}_{3}\right)-\mathrm{CH}-\mathrm{CH}_{2}-\mathrm{CH}=\mathrm{CH}-$ (C) (Fig. 2). Taking into account all of the above described spectroscopic data, the compound was considered a lanostane type triterpene with hydroxyl and olefinic moieties. In the nuclear Overhauser effect spectroscopy (NOESY) spectrum, the cross peaks observed
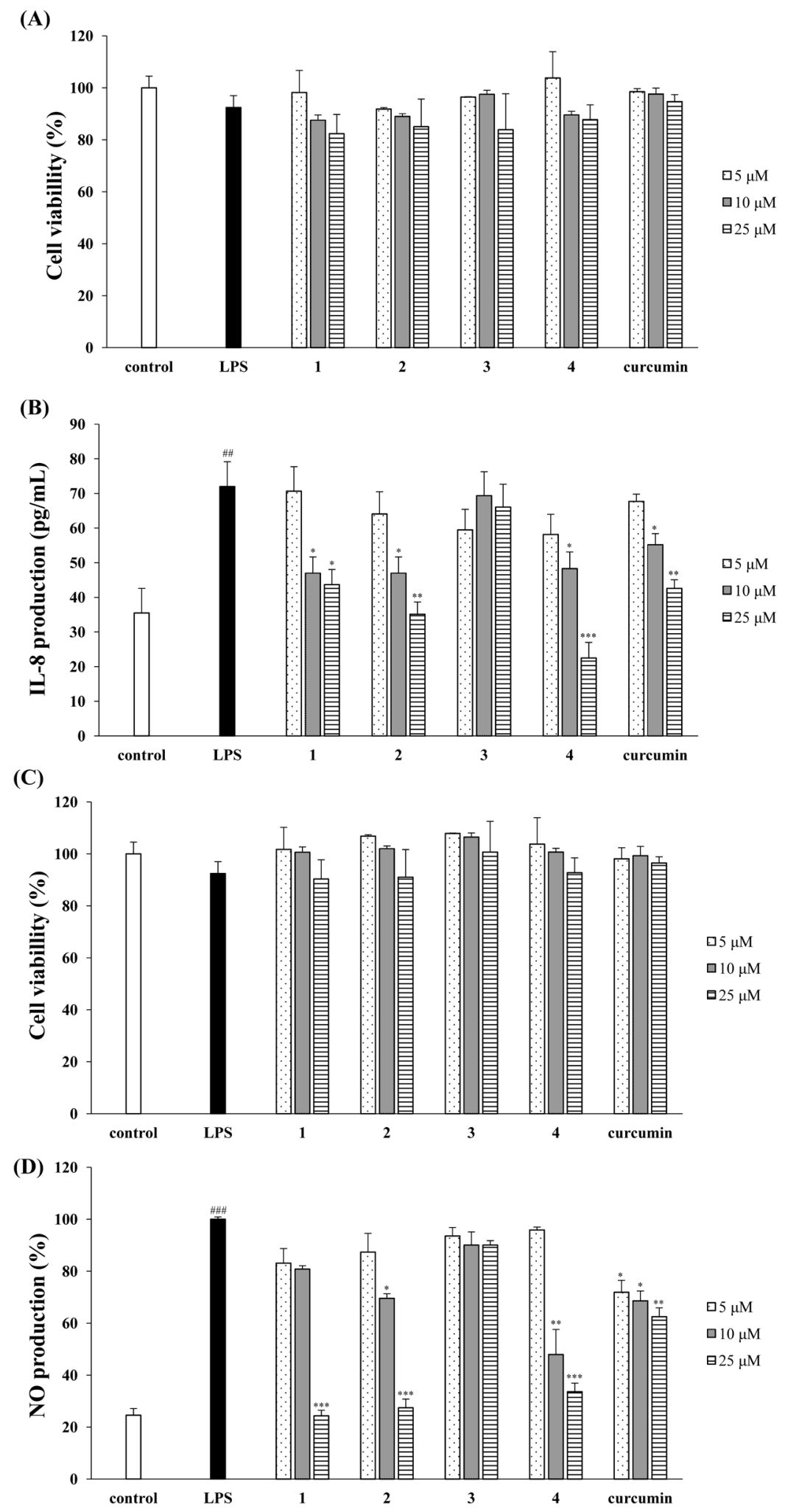

Fig. 3. Effects of Compound 4 on LPS-Induced IL-8 Production in HT-29 Cells and LPS-Stimulated NO Production in RAW264.7 Cells

HT 29 cells and RAW264.7 cells were pretreated in the presence of different concentrations of compound 4, then stimulated with $1 \mu \mathrm{g} / \mathrm{mL}$ LPS for $24 \mathrm{~h}$. (A, C) The cells viability was determinded with the MTT assay. (B) IL-8 level in culture media was measured with an ELISA kit. (D) The NO production in culture medium was measured using Griess reagents. Curcumin was used as the positive control. The values are expressed as the mean \pm S.D. $(n=3)$ of three individual experiments. ${ }^{\# \#} p<0.01$ and $\# \#<0.001$, compared with untreated control; * $p<0.05$, ${ }^{* *} p<0.01$ and $* * * p<0.001$, compared with LPS-treated control. 
between $\mathrm{CH}_{3}-18$ and $\mathrm{H}-8$, and between $\mathrm{CH}_{3}-19$ and $\mathrm{H}-8$ as well as the lack of a cross peak between $\mathrm{H}-5$ and $\mathrm{H}-8 / \mathrm{CH}_{3}-19$ further supported the lanostane-type skeleton (Fig. 2). On the basis of these data, compound $\mathbf{3}$ was determined to be $3 \beta$ hydroxy-lanost-9(11),23(24)-dien-25,26-diol, isolated for the first time from nature.

The three known compounds were identified as $3 \beta$ hydroxy-lanost-9(11),24(25)-dien-26-oic acid (1), (24S)-lanost9(11)-ene-3,24,25-triol (2), and leucastrin B (4) by comparing the measured spectroscopic data with published values. ${ }^{16-18)}$

We evaluated the effects of the triterpenoids isolated from $A$. japonica fruits on inflammatory responses using the cell line models of macrophage and colon epithelial cells that can mimic the intestinal epithelial cell condition during IBD. ${ }^{19)}$

Using HT-29 cells, we measured the effects of the four triterpenoids isolated from $A$. japonica by applying various concentrations $(5-25 \mu \mathrm{M})$ to the cells for $1 \mathrm{~h}$, incubating with $1 \mu \mathrm{g} / \mathrm{mL}$ LPS for $24 \mathrm{~h}$, followed by MTT assay. The LPS-treated groups and sample-treated groups showed $92.4 \%$ and over $85 \%$ cell viability compared to the non-treated control group, respectively (Fig. 3A). HT-29 cells secrete substantial amounts of IL- 8 when exposed to LPS. ${ }^{20)}$ Normal intestinal epithelial cells have the potential to secret the potent chemoattractant IL-8 and might contribute to inflammation as opposed to normal mucosa. ${ }^{20)}$ The inhibitors of the pro-inflammatory chemokine, IL-8, may be used for the treatment of immune-associ-
(A)
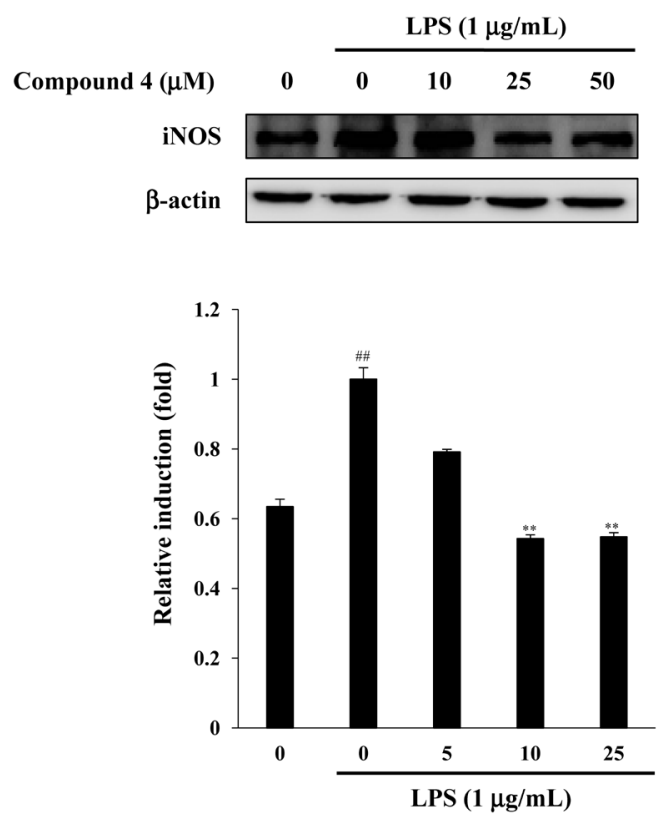

(B)
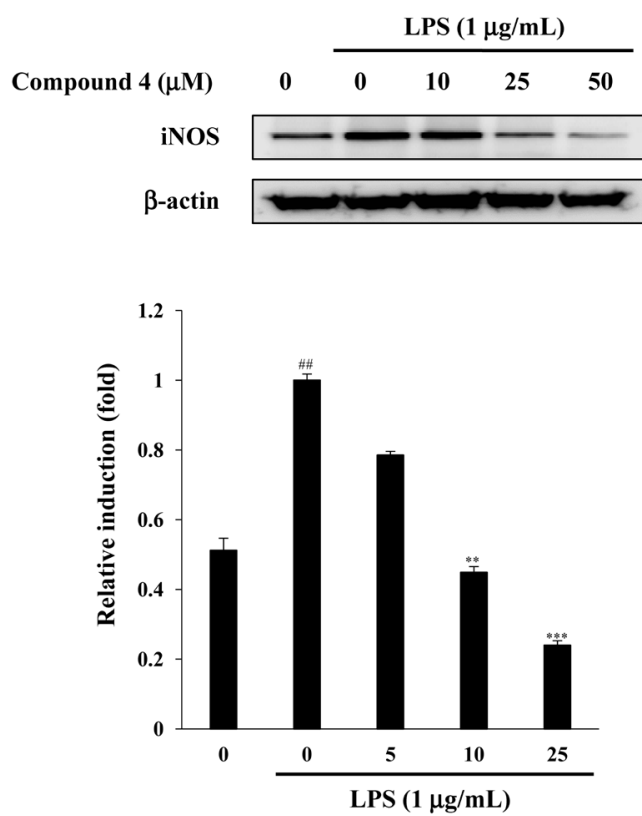

Fig. 4. Effects of Compound 4 on iNOS Expression in LPS-Stimulated HT-9 Cells and RAW264.7 Cells

Cells were pretreated with the indicated concentration of compound 4 for $1 \mathrm{~h}$ and stimulated with LPS $(1 \mu \mathrm{g} / \mathrm{mL})$ for $24 \mathrm{~h}$. The expression of iNOS and $\beta$-actin was determined by Western blot analysis using specific antibodies. The values are expressed as the mean \pm S.D. $(n=3)$ of three individual experiments. ${ }^{\prime} p<0.01$, compared with untreated control; ** $p<0.01$ and $* * * p<0.001$, compared with untreated control.

(A)

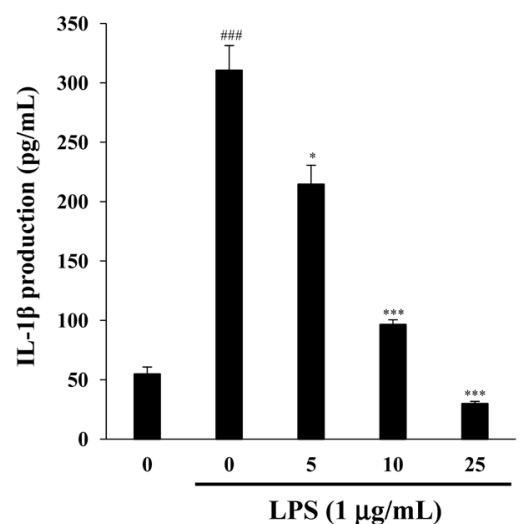

(B)

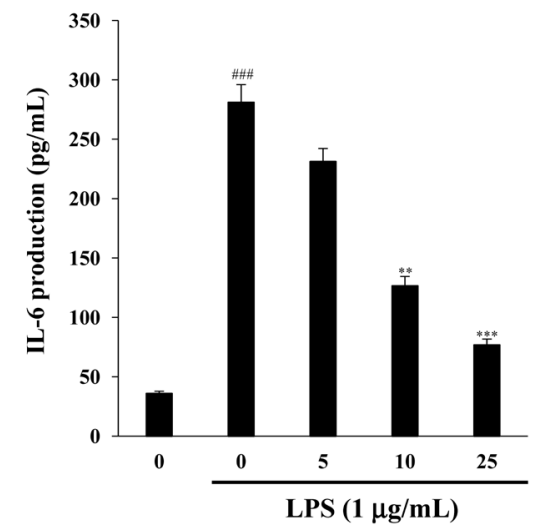

Fig. 5. Effects of Compound 4 on LPS-Induced Inflammatory Cytokine Production in RAW264.7 Cells

Cells pretreated with various concentrations of compound 4 for $1 \mathrm{~h}$ were stimulated with LPS ( $1 \mu \mathrm{g} / \mathrm{mL})$ for $24 \mathrm{~h}$. The amount of cytokines IL-1 $\beta$ (A) and IL-6 (B) in the culture medium was measured using manual ELISA kits, as described in Materials and Methods. The values are expressed as the mean \pm S.D. $(n=3)$ of three individual experiments. ${ }^{\# \#} p<0.01$, compared with untreated control; $* p<0.05, * * p<0.01$ and $* * * p<0.001$, compared with LPS-treated control. 
ated diseases, IBD and thus, we assessed the LPS-stimulated IL-8 expression of triterpenoids in HT-29 cells. Compounds 1, 2, and 4 effectively decreased the expression of IL-8, compared to curcumin, while compound $\mathbf{3}$ had no effect (Fig. 3B). Especially, compound 4 considerably attenuated IL-8 expression below the control level at a concentration of $25 \mu \mathrm{M}$.

RAW264.7 cells were treated with four triterpenoids for $1 \mathrm{~h}$, then cultured with $1 \mu \mathrm{g} / \mathrm{mL}$ LPS for $24 \mathrm{~h}$ followed by the MTT assay. The four triterpenoids exerted no significant cytotoxicity at concentrations up to $25 \mu \mathrm{M}$ (Fig. 3C). The production of $\mathrm{NO}$, a pleiotropic free radical messenger molecule, is promoted in human IBD tissues. ${ }^{21)} \mathrm{NO}$ is produced by iNOS, which is up-regulated in various forms of mucosal inflammation. ${ }^{21}$ The production of excess NO and inflammatory mediators is associated with inflammatory process. It has been reported that natural compounds have suppressive effects on NO and the secretion of inflammatory mediators for the development of therapeutic agents to treat inflammatory diseases. ${ }^{22,23)}$ Compounds 1, 2, and 4 concentration-dependently decreased NO production in comparison to the LPS-treated group (Fig. 3D). Compound 3 exerted no effect on NO production and seemed to hardly have any anti-inflammatory activity. At a concentration of $10 \mu \mathrm{M}$, compound 4 considerably suppressed NO production up to $47.9 \%$, whereas compounds $\mathbf{1}, \mathbf{2}$, and curcumin attenuated NO production up to $80.8,69.6$, and $68.6 \%$, respectively.

From the results in Fig. 3, we suggest that compound 4 has the most potent anti-inflammatory effect in both LPSstimulated RAW264.7 cells and HT-29 cells among the four triterpenoids isolated from $A$. japonica. It has been reported that iNOS is necessary for the production of NO. In order to investigate the effects of compound $\mathbf{4}$ on the expression of LPS-induced inflammatory proteins, iNOS were evaluated in RAW264.7 cells and HT-29 cells. As showed in Fig. 4, LPS treatment without compound $\mathbf{4}$ significantly increased the expression of iNOS protein, while pretreatment of compound 4 exhibited a concentration-dependent inhibition of the LPSinduced expression of this protein.

Activated macrophages and colon epithelial cells produce pro-inflammatory cytokines such as IL-1 $\beta$ and IL-6. To confirm the anti-inflammatory activity of compound 4 , we measured the LPS-induced production of IL- $1 \beta$ and IL- 6 using an ELISA kit. IL- $1 \beta$ and IL- 6 production was significantly inhibited by compound 4 at concentrations ranging from $5 \mu \mathrm{M}$ to $25 \mu \mathrm{M}$ (Fig. 5). Mahida et al. demonstrated that LPS elevates the production of IL- $1 \beta$ in mononuclear cells from active IBD mucosa but not those from normal mucosa. ${ }^{24)}$ Increased IL-6 expression by lamina propria macrophages has been observed in experimental colitis and in IBD patients. ${ }^{5,25)}$ The suppression of IL-6 signaling with monoclonal antibodies was effective in the inhibition of chronic intestinal inflammation in mouse models, which suggests IL- 6 as a potential therapeutic target in IBD. ${ }^{5)}$ Likewise, proinflammatory cytokines, IL-1 $\beta$ and IL- 6 , are amplified in the IBD-affected intestine. ${ }^{26}$ High secretion of mucosal IL- $1 \beta$ in IBD could be caused by infiltrating macrophages, which have been found to migrate in large numbers into the inflamed mucosa and the intestinal lumen during UC and $\mathrm{CD}^{2}{ }^{25}$ Furthermore, IL- $\beta$ can enhance the secretion of potent chemotactic cytokines, IL- 8 by stimulating different cell types, and IL-8 elevates the migration of granulocytes into the intestinal mucosa. ${ }^{26)}$
Acknowledgments This work was supported by the National Research Foundation of Korea (NRF) Grant funded by the Korea government (MSIP) (No. NRF-2017R1C1B2005934). This work was supported by Suncheon Research Center for Natural Medicines.

Conflict of Interest The authors declare no conflict of interest.

Supplementary Materials The online version of this article contains supplementary materials. Refer to Web version on Pubmed Central for supplementary material.

\section{REFERENCES}

1) Ward PA. The harmful role of c5a on innate immunity in sepsis. $J$. Innate Immun., 2, 439-445 (2010).

2) Gupta RA, Motiwala MN, Dumore NG, Danao KR, Ganjare AB. Effect of piperine on inhibition of FFA induced TLR4 mediated inflammation and amelioration of acetic acid induced ulcerative colitis in mice. J. Ethnopharmacol., 164, 239-246 (2015).

3) Zhang X, Mosser DM. Macrophage activation by endogenous danger signals. J. Pathol., 214, 161-178 (2008).

4) Piwowarski JP, Kiss AK, Granica S, Moeslinger T. Urolithins, gut microbiota-derived metabolites of ellagitannins, inhibit LPS-induced inflammation in RAW264.7 murine macrophages. Mol. Nutr. Food Res., 59, 2168-2177 (2015).

5) Neurath MF. Cytokines in inflammatory bowel disease. Nat. Rev. Immunol., 14, 329-342 (2014).

6) Peyrin-Biroulet L, Desreumaux P, Sandborn WJ, Colombel JF. Crohn's disease: beyond antagonists of tumour necrosis factor. Lancet, 372, 67-81 (2008).

7) Rogler G, Andus T. Cytokines in inflammatory bowel disease. World J. Surg., 22, 382-389 (1998).

8) MacMicking J, Xie QW, Nathan C. Nitric oxide and macrophage function. Annu. Rev. Immunol., 15, 323-350 (1997).

9) Zhang Y, Wang Y, Zhang F, Wang K, Liu G, Yang M, Luan Y, Zhao Z, Zhang J, Cao X, Zhang D. Allyl methyl disulfide inhibits IL-8 and IP-10 secretion in intestinal epithelial cells via the NF-кB signaling pathway. Int. Immunopharmacol., 27, 156-163 (2015).

10) Laveti D, Kumar M, Hemalatha R, Sistla R, Naidu VG, Talla V, Verma V, Kaur N, Nagpal R. Anti-inflammatory treatments for chronic diseases: a review. Inflamm. Allergy Drug Targets, 12, 349-361 (2013).

11) Kim ST, Kim JD, Ahn SH, Ahn GS, Lee YI, Jeong YS. Hepatoprotective and antioxidant effects of Alnus japonica extracts on acetaminophen-induced hepatotoxicity in rats. Phytother. Res., 18, 971-975 (2004)

12) Jeong CS. Anti-inflammatory and analgestic activity of Alnus japonica cortex ethanol extract. Korean J. Pharmacogn., 34, $233-$ 236 (2003).

13) Sati SC, Sati N, Sati OP. Bioactive constituents and medicinal importance of genus Alnus. Pharmacogn. Rev., 5, 174-183 (2011).

14) Lee SG, Kim M, Kim CE, Kang J, Yoo H, Sung SH, Lee M. Quercetin 3,7-O-dimethyl ether from Siegesbeckia pubescens suppress the production of inflammatory mediators in lipopolysaccharideinduced macrophages and colon epithelial cells. Biosci. Biotechnol. Biochem., 80, 2080-2086 (2016).

15) Sung SH, Lee M. Anti-adipogenic activity of a new cyclic diarylheptanoid isolated from Alnus japonica on 3T3-L1 cells via modulation of PPAR $\gamma, \mathrm{C} / \mathrm{EBP} \alpha$ and SREBP1c signaling. Bioorg. Med. Chem. Lett., 25, 4648-4651 (2015).

16) Li RT, Han QB, Zhao AH, Sun HD. Micranoic acids A and B: two new octanortriterpenoids from Schisandra micrantha. Chem. Pharm. Bull., 51, 1174-1176 (2003). 
17) Ukiya M, Akihisa $T$, Yasukawa $K$, Kasahara $Y$, Kimura $Y$, Koike K, Nikaido T, Takido M. Constituents of compositae plants. 2. Triterpene diols, triols, and their 3-o-fatty acid esters from edible chrysanthemum flower extract and their anti-inflammatory effects. J. Agric. Food Chem., 49, 3187-3197 (2001)

18) Miyaichi Y, Segawa A, Tomimori T. Studies on Nepalese crude drugs. XXIX. Chemical constituents of Dronapuspi, the whole herb of Leucas cephalotes Spreng. Chem. Pharm. Bull., 54, 1370-1379 (2006).

19) Verma N, Ahuja V, Paul J. Profiling of ABC transporters during active ulcerative colitis and in vitro effect of inflammatory modulators. Dig. Dis. Sci., 58, 2282-2292 (2013).

20) Schuerer-Maly CC, Eckmann L, Kagnoff MF, Falco MT, Maly FE. Colonic epithelial cell lines as a source of interleukin-8: stimulation by inflammatory cytokines and bacterial lipopolysaccharide. Immunology, 81, 85-91 (1994).

21) Cross RK, Wilson KT. Nitric oxide in inflammatory bowel disease. Inflamm. Bowel Dis., 9, 179-189 (2003).

22) Gao Y, Fang L, Cai R, Zong C, Chen X, Lu J, Qi Y. ShuangHuang-Lian exerts anti-inflammatory and anti-oxidative activities in lipopolysaccharide-stimulated murine alveolar macrophages. Phytomedicine, 21, 461-469 (2014).

23) Johnson TA, Sohn J, Inman WD, Bjeldanes LF, Rayburn K. Lipophilic stinging nettle extracts possess potent anti-inflammatory activity, are not cytotoxic and may be superior to traditional tinctures for treating inflammatory disorders. Phytomedicine, 20, 143-147 (2013)

24) Mahida YR, Wu K, Jewell DP. Enhanced production of interleukin 1-beta by mononuclear cells isolated from mucosa with active ulcerative colitis of Crohn's disease. Gut, 30, 835-838 (1989).

25) Reinecker HC, Steffen M, Witthoeft T, Pflueger I, Schreiber S, MacDermott RP, Raedler A. Enhanced secretion of tumour necrosis factor-alpha, IL-6, and IL-1 beta by isolated lamina propria mononuclear cells from patients with ulcerative colitis and Crohn's disease. Clin. Exp. Immunol., 94, 174-181 (1993).

26) Mitsuyama K, Toyonaga A, Sasaki E, Watanabe K, Tateishi H, Nishiyama T, Saiki T, Ikeda H, Tsuruta O, Tanikawa K. IL-8 as an important chemoattractant for neutrophils in ulcerative colitis and Crohn's disease. Clin. Exp. Immunol., 96, 432-436 (1994). 